Vol. 9 No.1 January 2020

P-ISSN: 2301-9913, E-ISSN: 2597-9132

DOI: http://dx.doi.org/10.31000/globish.v7i2

\title{
The Student's Learning Style And Their Writing Skill At SMK Tiara Aksara
}

\author{
1Eka Sari, ${ }^{2}$ Ikhfi Imaniah, 3Imtihan Hanim \\ ${ }^{123}$ English Education Study Program Teachers Training and Education Faculty of Muhammadiyah \\ University Tangerang Jl. Perintis Kemerdekaan I/ 33 Cikokol, Tangerang-Indonesia. \\ Email: 1ekasputri04@gmail.com, ${ }^{2}$ ikhfiimaniah@umt.ac.id, ${ }^{3}$ imtihan hanim@umt.ac.id
}

\begin{abstract}
Writing is an activity that not only need physical act but also mental act. Students can put their statements, idea and opinion in composing writing. Moreover, students learn with visually, auditory and kinesthetic. Students with multi learning style usually better in learning and understand lessons, particularly in writing. Due to the statement, this study is aimed to find out the correlation between students' learning style and their writing skill. This study uses survey quantitative method and analyze the data by using statitisctical hypotheses. Based on the data analysis, it was found that student's learning style was not normally distributed, whereas the data of writing test was normally distributed. Therefore, the researchers used non-parametric statistics to analyze the hypotheses. Kendall Tau calculation was used and obtained that Zcount $((0,35)<$ Ztable $(1,96)$ with significant 0,05 . Thus, $\mathrm{H} 0$ is accepted and $\mathrm{Hi}$ is rejected. It means that there is no correlation between students' learning style and their writing skill. In this case, learning style were not dominat factors affected writing skill.
\end{abstract}

Keywords: Learning Style, Writing Skill, Recount Text.

\section{INTRODUCTION}

Writing is an activity that take place within context to accomplish special purpose and appropriately shaped for its intended audience" Hamp-Lyons and Kroll in Weigle (2002). Furthermore, another definition about writing comes from Nunan (2003, p. 88) state "writing is physical and mental activity". Writing is called physical activity because it is an activity of collecting the words in some medium. Besides, writing is called mental activity it is work of inventing the ideas, thinking about how to express and organize ideas into statement and paragraphs that will impress the readers. It means that writing is the collaboration activity between physical act and mental working in developing ideas into statements and paragraphs that are conveyed through the reader and through writing the students can deliver their ideas writtenly. The students can express their ideas in a letter, book, or article. It is related to the thinking process and ideas in written form. Writing process is more complex because the students need pay attention on the overall pattern or structure of the text that students know what they have written.

Although on reality, not all of the students have good in writing. There are some factors contributed such as learning motivation, learning style, vocabularies mastery,

Received July 10, 2019; Revised July 20, 2019 ; Accepted August 25, 2019 
P-ISSN: 2301-9913, E-ISSN: 2597-9132

DOI: http://dx.doi.org/10.31000/globish.v7i2

grammar mastery and emotional problem. These factors can affect the student's writing skill. The students learning styles is one of the factors that influence student's writing skill. According to MacKeracher $(2004$, p. 71) states "that learning style is behavior that serve as relatively stable indicators of how learners perceive, interact with, and respond to the learning environment". In addition Brown (2000, p. 120) defines "learning styles as the manner in which individuals perceive and process information in learning situations". Base on the definitions above the students have different ways to get information in learning situations.

Related to the researchers' pre-observation in writing class of eleventh grade students at SMK Tiara Aksara, the students have different style in understanding the material about writing that explained by the teacher not only caused by the students' low motivation and their difficulty to express some ideas in writing. It is because they do not master vocabulary. Besides that, the learning and teaching process cannot utilize the language laboratory provided there. So, it seems the teaching process still uses conventional method. To solve the problem, the students must be equipped with vocabulary before writing. The students are lack of vocabulary and grammar mastery that make students difficult in writing.

\section{WRITING}

In learning English writing is one of important skills that students should master. Writing is a purposeful activity because in writing students must know what will they write. Students can communicate and explore their ideas in written form or a message. However, students will find challenges if they are not mastery in grammar and vocabulary in writing, so they must be familiar in grammar and vocabulary mastery. According to Spratt et.al. (2005, p. 26) "Writing is productive skill which involves communicating a message by making signs on a page". Whereas, Brown (2001, p. 335) describe written products as "the result of thinking, drafting, and revising procedures that require specialized skill, skills that on every speaker develops naturally". Furthermore, Harmer (2004) states that writing encourages students to focus on accurate language use. It is because students consider the language use when the students engage in their writing process. This activity will provoke language development because the students resolve problems what writing puts in students' minds. It means that writing is not a simple and instant process. Therefore, writing is not easy skill. So, the students must practice a lot to improve their writing skill.

\section{LEARNING STYLE}

Keefe in Martinez (2001, p. 82) argues that "learning style is the composite of characteristic cognitive, affective, and physiological factors that serve as relatively stable indicators of how a learner perceives, interact with, and responds to the learning environment". In other word, learning style is the combination of learner ability and knowledge to achieve goal from learning process. Furthermore, Tutton (2013) states

The Student's Learning Style And Their Writing Skill At SMK Tiara Aksara;

${ }^{1}$ Eka Sari, ${ }^{2}$ Ikhfi Imaniah, ${ }^{3}$ Imtihan Hanim 
that one of the simple's theories is that proposed by Flemin, there are four types of learning style, as follows: Visual learning style this is preferred learning style by seeing and memorizing visual components. If the child is drawn in art, painting, craft, and books with picture, then the child is probably a visual learner. The second is auditory learning style this is preferred learning style by listening, remembering, and following instructions. If the child remembers most of the things that he hears and responds accurately to most of the commands and instructions given to him, that child is a verbal or auditory learner. The third is reading/ writing preferred style this style is center around reading and referencing along with possible writing and note-taking. The student prefers to take notes which are written in a form for him to copy. The last is kinesthetic learning style, the student loves to explore and understand thing by move or play around. It is possible student become more active during learning.

\section{RESEARCH METHOD}

The research method that is used in this research is quantitative. The researchers conducted the research in eleventh grade students at SMK Tiara Aksara that is located on Jl. H Aning Tangerang. The researchers selected the school because the students at SMK Tiara Aksara still lack in English skill particularly in writing English skill. In this research the data was focused on the correlation between students' learning style and writing skill. Therefore, this method will be applied in finding the correlation between eleventh grade students' learning style and writing skill at SMK Tiara Aksara. The population in this research are the students of eleventh grade at SMK Tiara Aksara consist 99 students but only 51 students that the researcher took as sample.

The data collecting instruments in this research was taken from result of questionnaire and writing skill of recount text.in collecting the data, the researchers gave the students' learning style questionnaire, verified the students' response, identified the students' learning style and gave the score based on following criteria. Furthermore for writing text, the researchers asked the students to write a recount text about their experience and then the researchers collected the data of students writing recount text.

After collecting the data, the researchers analyzed students' learning style questionnaire and writing. The data analyzed by scoring the students' learning style questionnaire was finding by sum up the total respond's score from the questionnaire. Then the researchers found the frequency distribution of each the data by using the formula:

$\mathrm{J}=$ Score $\max$ Score $\min$

$\mathrm{K}=1+3,3 \log \mathrm{n}$

$\mathrm{P}=\mathrm{j} / \mathrm{k}$

Descriptions:

$\mathrm{P}=$ range of the class

$\mathrm{J}=$ scope

$\mathrm{K}=$ total of the class

After collecting data from two instruments, the data are analyzed by using Kendall Tu correlation in order to see whether any correlation between two variables. The two

The Student's Learning Style And Their Writing Skill At SMK Tiara Aksara

${ }^{1}$ Eka Sari, ${ }^{2}$ Ikhfi Imaniah, ${ }^{3}$ Imtihan Hanim. 
P-ISSN: 2301-9913, E-ISSN: 2597-9132

DOI: http://dx.doi.org/10.31000/globish.v7i2

set of scores calculated and the result showed there is no relationship between these two variables. According to Sugiyono (2015, p.148) states that inferential statistic is the statistical techniques used to analyze the sample data and the results are applied to the population. The researchers used the inferential statistic by normality test, homogeneity test, simple regression, regression line linearity test, regression equation significant test, and Kendall Tau. The formula of Kndall Tau as follow:

$\overline{-\sqrt{ }()} \sqrt{\sqrt{ }()}$

$\mathrm{T}_{\chi}=1 / 2 \sum \mathrm{t}(\mathrm{t}-1)$ and $\mathrm{T}_{\gamma}=1 / 2 \Sigma \mathrm{t}(\mathrm{t}-1) \mathrm{t}$

$=$ the number of same rank

\section{RESEARCH FINDING AND DISCUSSION}

First, the finding shows the highest score of writing was 83 and 30 for the lowest score. Second, the researchers found that coefficient calculation with significant 0,05 above shows that $\mathrm{Z}$ count $0,35<\mathrm{Z}$ table 1,96 . Thus, $\mathrm{H}_{0}$ is accepted and $\mathrm{H}_{\mathrm{i}}$ is rejected, it means that there is no correlation between students' learning style and writing skill. The finding contradicts and refuses the theory of students' learning style which have relationship with students' writing skill. The research analysis affected by data which are not normally distributed and homogeneous since learning style data has high difference from writing data. Also, the researchers did not classify and analyzed the dominant learning style. These probably factors that affect the result.

The researchers have found limitation in research process since unsupported condition such as limitation of time. When the students were writing the recount texts, they need extra time to finish their writing The researchers assume that this because they have difficulty in writing and lack of vocabulary and grammar. So, they need extra time to finish their writing.

In short, learning style were not dominat factors affected writing skill. The factors might from student's grammar mastery, vocabularies, and their internal factors such as laziness, attention in the learning process, and motivation in learning particulary in writing class activity.

\section{CONCLUSION}

The researchers pointed out the conclusions that there was no correlation between eleventh grade students' learning style and their writing skill at SMK Tiara Aksara because the data result of Kendall Tau correlation coefficient shows that $\mathrm{Z}$ count $0,35<\mathrm{Z}$ table 1,96. Thus, $\mathrm{HO}$ is accepted and $\mathrm{Hi}$ is rejected, it means that there is no correlation between students' learning style and writing skill. Therefore, the reserachers arises some suggestions that hopefully can be applied in teaching and learning processs.

The Student's Learning Style And Their Writing Skill At SMK Tiara Aksara;

${ }^{1}$ Eka Sari, ${ }^{2}$ Ikhfi Imaniah, ${ }^{3}$ Imtihan Hanim 
P-ISSN: 2301-9913, E-ISSN: 2597-9132

DOI: http://dx.doi.org/10.31000/globish.v7i2

First, the teachers need to know students learning style to choose and use appropriate method and technique in teaching English. Second, the teacher need to motivate their students in learning, particularly in writing. Third, students are suggested to be more diligent in practice their writing. Forth, students are suggested to improve their grammar and vocabulary, so it can help them to be easier in composing writing recount text.

\section{REFEREENCES}

Arikunto, S. (2013). Prosedur Penelitian Suatu Pendekatan Praktek. Jakarta: PT. Rineka Cipta. Brown, H., Douglas. (2004). Language Assessment: Principles and Classroom Practice. United Kingdom: Pearson Longman.

Browne, Ann. (2007). Teaching and Learning Communication, Language and Literacy. London: Paul Chapman Publishing

Brown, H.Douglas.(2004) Language Assessment Principle And Classroom Practices.Second Edition. New York: Pearson Education

Brown, H. Douglas.(2007) Language Assessment Principle And Classroom Practices. Third Edition. New York: Pearson Education.

Emily F, C. 1999. Teaching Beginning Reading And Writing. Amerika: ASCD.

Emawati, M. 2014. Hubungan Gaya Belajar Dengan Kemampuan Menulis Puisi Sekolah Menengah Negri 2 Tempunak Tahun Pelajaan 2014/2015. Jurnal. Sintang:STKIP

Fanny, T. 2015. The Correlation Between Students Learning Style And Their Writing Achievement At Third Semester Students of English Departement In Stkip Pgri West Sumatra. Jurnal. Sumatra Barat: STKIP PGRI.

Harmer, J. (2004). How To Teach writing. UK: Longman. (2007). How To Teach English. UK: Longman.

Imaniah, I. 2017. Teaching English As Foreign Language (Teaching And Learning Strategies).Tangerang: FKIP UMT PRESS

James, G. S (2009). Writing for the Mass Media.Seventh Edition. Amerika: Pearson Education. Lefever, D. M. 2004. Learning Styles: Reaching Everyone God Gave You to Teach, (2nd edition). Colorado: Colorado Springs.

Nation, I. S. P. (2009). Teaching ESL/EFL Reading and Writing, New York: Routledge. Nunan, D. 2003. Practical Engllish Language Teaching "Exploring Skills". New York: McGraw Hill.

Richards, J. C., \& Renandya, W. A. (2002). Methodology in Language Teaching. University Press: Cambridge.

Riadi, E.(2014) Metode Statsitika Parametrik dan Non Parametrik, Edsisi ke-3. Tangerang: PT Pustaka Mandiri.

Sugiyono, (2015). Metode Penelitian Pendidikan. Bandung: Alfabeta.

Sugiyono, (2016). Metode Penelitian Pendidikan. Bandung: Alfabeta.

Santi, W.P. Zainal, A. Dewi, N. 2011. The Correlation Between Learning Style and Reading

Comprehension. Pontianak: FKIP Untan Pontiana

The Student's Learning Style And Their Writing Skill At SMK Tiara Aksara

${ }^{1}$ Eka Sari, ${ }^{2}$ Ikhfi Imaniah, ${ }^{3}$ Imtihan Hanim. 
P-ISSN: 2301-9913, E-ISSN: 2597-9132

DOI: http://dx.doi.org/10.31000/globish.v7i2

Spratt, M. P, Alan. Williams, M (2005). The TKT Course. New York: Cambridge University Press. Weigle, S. C. (2002). Assessing Writing. United Kingdom: Cambridge University

William, H. 2009. Dicipline and Learning Style; An Educator's Guide. New York: performance learning stye 